\title{
EKSTRAK BAWANG TIWAI (ELEUTHERINE AMERICANA MERR) SEBAGAI ANTIOKSIDAN PADA MINYAK KELAPA
}

\author{
Suroto Hadi Saputra \\ Balai Riset dan Standardisasi Industri Samarinda
}

\begin{abstract}
Tiwai onion bulb extract (EBT) contain phenol compounds that be used as an antioxidant ingredients. Utilization tiwai onion bulb extract as an antioxidant is expected to increase the value and utilization tiwai onion bulbs. This research was conducted to obtain tiwai onion bulb extract concentration as antioxidant ingredients of coconut oil. Extraction process is done by adding $96 \%$ ethanol solvent to onion tiwai flour and then incorporated into the glass beaker, allowed to stand for 24 hours and then filtered to obtain a liquid extract. Rendement tiwai onion bulb extract solvent $96 \%$ ethanol is $10,2 \%$. The average value of total phenol content of onion bulb extract tiwai solvent $96 \%$ ethanol is $0,043 \pm 0,001 p p m$. The liquid extract was then performed vacuum evaporation and the obtained further extract tiwai and then put in oven vacuum. Extract obtained is then inserted into the coconut oil, and then analyzed with the parameters of color, odor, proxide number and acid number, with storage time for 3 months. Based on test result, it is obtained that the concentratations of tiwai onion bulb extract $100-200 \mathrm{mg} / \mathrm{kg}$ was able to maintain storage time of coconut oil until the 3 mont period specified in the study.
\end{abstract}

Keywoods : extract, onion tiwai, antioxidants, coconut oil.

\section{PENDAHULUAN}

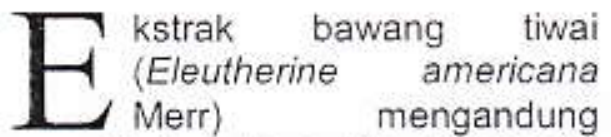
senyawa kimia antara lain Flavonoid, Aldehid keton, Asam karboksilat, Glikosida, Tanin, Fenol, Karbohidrat, dan Protein.

Minyak kelapa digunakan sebagai bahan baku industri, atau minyak goreng. Minyak kelapa sebagimana minyak nabati lainnya merupakan senyawa trigliserida yang tersusun atas berbagai asam lemak dan $90 \%$ diantaranya merupakan asam lemak jenuh. Minyak kelapa kaya akan asam lemak jenuh meliputi asam laurat, meristat, palmitat dan stearat dan juga memiliki asam lemak tak jenuh meliputi asam oleat, linoleat dan linolenat.

Minyak kelapa yang belum dimurnikan mengandung sejumlah kecil komponen bukan lemak seperti fosfatida, gum, sterol, tokoferol, asam lemak bebas, protein dan karoten. Sterol berfungsi sebagai stabilizer dalam minyak dan tokoferol sebagai antioksidan.

Kerusakan minyak yang utama adalah timbulnya bau dan rasa tengik yang disebut proses ketengikan yang dimulai dengan pembentukan radikal bebas yang disebabkan oleh faktorfaktor yang dapat mempercepat reaksi seperti cahaya dan panas. 
Reaksi oksidasi ini dapat juga berlangsung bila terjadi kontak antara sejumlah oksigen dengan minyak. Terjadinya rekasi oksidasi ini akan mengakibatkan bau tengik pada minyak. Salah satu cara yang dilakukan untuk mencegah terjadinya reaksi ketengikan ini adalah denngan menggunakan bahan antioksidan.

Bahan antioksidan yang sering digunakan dalam industri minyak dapat berasal dari bahan sintetis dan alami. Bahan antioksidan yang berasal dari sintetis antara lain butylated hydroxyanisole (BHA), butylated hydroxytoluene (BHT), tertierbutyl hydroquinon (TBHQ) dan propylgallate (PG). Sedangkan bahan antioksidan yang berasal dari alami antara lain tokoferol dan vitamin C.

Penggunaan bahan antioksidan yang berasal dari sintetis bila ditijau dari kesehatan dapat mendatangkan dampak negatif seperti munculnya penyakit kanker, dan gangguan liver, bila penggunaan bahan tersebut melampau batas ( $\mathrm{di}$ atas ambang batas). Di negara-negara maju penggunaan bahan antioksidan sintetis tidak dianjurkan karena bersifat karsinogenik. Menurut Andarwulan (1996) berbagai studi mengenai BHA dan BHT menunjukkan bahwa komponen ini dapat menimbulkan tumor pada hewan percobaan pada penggunaan dalam jangka panjang.

Sedangkan bahan antioksidan yang berasal dari alami, bila ditinjau sisi kesehatan relatif aman dan bersahabat. Relatif tidak ada efek negatif yang muncul dari bahan tersebut yang dapat mengganggu kesehatan manusia.

Semakin

meningkatnya permintaan akan bahan antioksidan alami mendorong banyak peneliti untuk terus menggali dan mencari labih jauh bahan pangan yang dapat menjadi sumber antoksidan alami.

Kebanyakan sumber antioksidan alami adalah tumbuhan dan umumnya merupakan senyawa fenolik yang tersebar diseluruh bagian tumbuhan, baik di kayu, biji, umbi, buah, daun, akar, bunga dan serbuk sari.

Menurut Suroto dan Sampepana (2007) bahwa umbi bawang tiwai memiliki senyawa antara lain flavonoid, aldehid keton, asam karboksilat, glikosida, tanin, fenol, karbohidrat, dan protein.

Menurut Suroto (2007) hasil ekstrak umbi bawang tiwai (Eleutherine americana Merr) dengan pelarut methanol dan air panas memiliki persen antioksidan sebesar $61 \pm 0,8 \%$ dan $5 \pm$ $0,3 \%$.

Menurut Saputra (2010), ekstrak umbi bawang tiwai dengan pelarut etanol memiliki aktivitas antioksidan antara lain aktivitas antioksidan total $90,18 \pm 0,27 \%$, kapasitas penangkapan radikal bebas $78 \pm 0,002$, daya reduksi $1,02 \pm 0,01$, dan spesies oksigen reaktif $1,239 \pm 0,035$.

Salah satu bahan yang menarik untuk diteliti sebagai sumber komponen aktif antioksidan adalah ekstrak umbi bawang tiwai (Eleutherine americana Merr) sebagai antioksidan minyak kelapa.

Tujuan dari penelitian adalah untuk memperoleh konsentrasi ekstrak umbi bawang tiwai sebagai antioksidan minyak kelapa.

\section{BAHAN DAN METODA}

\section{Bahan dan alat}

Bahan yang digunakan pada penelitian ini adalah umbi bawang tiwai (Eleutherine americana Merr), ethanol $96 \%$, minyak kelapa, penutup karet, lembaran timah, kertas saring, label nama, $\mathrm{KI}, \mathrm{Kloroform}, \quad \mathrm{Na}_{2} \mathrm{~S}_{2} \mathrm{O}_{3}$, $\mathrm{CH}_{3} \mathrm{COOH}, \mathrm{BHT}$.

Sedangkan alat yang digunakan antara lain beaker glas, labu takar, erlenmyer, corong, gelas ukur, timbangan digital, pengaduk, blender, shaker dan rotary vakum evaporator.

\section{Metode}

Sampel bubuk umbi bawang tiwai $200 \mathrm{~g}$ direndam dengan 3 cairan etanol (a) $500 \mathrm{ml}$ selama 24 jam dengan 
dibantu pengocokan (shaking). Selanjut nya larutan ekstrak disaring dengan menggunakan kertas saring kemudian dipekatkan dengan rotary vakum evaporator.

Pengeringan ekstrak selanjutnya dilakukan dengan pengeringan vakum untuk memperoleh padatan ekstrak etanol.

Percobaan dilakukan dengn 2 (dua) perlakuan masing-masing dengan penambahan antioksidan (A) yaitu penambah an ekstrak umbi bawang tiwai $\left(a_{1}\right)$ dan penambahan antioksidan BHT $\left.\quad a_{2}\right)$ Konsentrasi masing antioksidan $0 \mathrm{mg}, 100 \mathrm{mg}, 150 \mathrm{mg}$ dan $200 \mathrm{mg}$.

Parameter dalam peneliti an ini antara lain sifat fisik minyak yaitu warna dan bau, sifat kimia minyak yaitu bilangan peroksida dan bilangan asam. Analisa sifat fisik minyak warna dan bau dilakukan secara kualitatif. Sedangkan sifat kimia minyak bilangan peroksida dan bilangan asam dilakukan secara kuantitatif. Pengamatan fisik yaitu warna dan bau Mengacu pada SNI-3741-1995. Analisa bilangan peroksida dan Bilangan asam Mengacu pada SNI-3741-1995.

\section{HASIL DAN PEMBAHASAN}

\section{Pengamatan fisik minyak kelapa}

Hasil pengamatan fisik minyak kelapa berupa warna dilakukan untuk mengetahui apakah ada perubahan selama waktu yang telah ditetapkan dalam penelitian sebagai mana tersaji pada Tabel 1. Hasil penelitian ini menunjukkan bahwa warna minyak kelapa pada pengamatan selama 2

bulan masih memiliki warna muda jernih (normal).

Menurut Ketaren (1986) Zat warna dalam minyak terdiri dari 2 (dua) golongan yaitu zat warna alamiah dan warna dari hasil degradasi zat warna alamiah. Zat warna alam yang termasuk golongan ini terdapat secara alamiah di dalam bahan yang mengandung minyak dan ikut terekstrak bersama minyak pada saat proses ekstraksi. Zat warna ini terdiri dari a dan $\beta$ karoten. Zat warna ini menyebabkan minyak berwarna kuning, kehijau-hijauan dan kemerah-merahan.

Namun setelah memasuki bulan ke tiga warna minyak kelapa tanpa pemberian antioksidan mengalami perubahan yaitu menjadi keruh atau kuning kecoklatan (abnormal), bila dibandingkan dengan adanya pemberian antioksidan $\mathrm{BHT}$ maupun EBT. Hal ini diduga karena warna minyak kelapa tanpa pemberian antioksidan mudah mengalami peruraian warna.

Hal ini diperjelas oleh Ketaren (1986) bahwa warna keruh atau gelap disebabkan oleh proses oksidasi terhadap tokoferol (vitamin E). Selain itu juga disebabkan pada proses pengolahan dan penyimpan an yaitu suhu pemanasan yang terlalu tinggi pada waktu pengepresan dengan cara hidraulik atau expeller, sehingga minyak teroksidasi.

Warna minyak kelapa pada kontrol masih memenuhi syarat SNI 3741-1995 pada umur simpan 2 bulan yaitu muda jernih namun setelah umur simpan 3 bulan tidak lagi memenuhi syarat. Sedangkan warna minyak kelapa yang diberi antioksidan EBT dan BHT pada umur simpan 3 bulan masih memenuhi syarat SNI 3741-1995.

Sebagaimana hasil pengamatan tentang sifat fisik minyak kelapa mengenai bau tersaji pada Tabel 1 , Bahwa pada saat pengamatan bulan ketiga minyak kelapa tanpa antioksidan mengalami perubahan bau (tengik) bila dibandingkan dengan pemberian antioksidan BHT maupun EBT. Hal ini di duga bahwa minyak kelapa tanpa antioksidan mngalami oksidasi sehingga menyebabkan bau (tengik).

Menurut Winarno (1997) minyak bersifat mudah menyerap bau. Apabila bahan pembungkus dapat menyerap minyak, maka minyak yang terserap ini akan teroksidasi oleh udara sehingga rusak dan berbau. Bau dari bagian minyak yang rusak ini akan diserap oleh minyak yang ada dalam 
bungkusan yang mengakibatkan seluruh minyak menjadi rusak.

Diperjelas oleh Buckle A.K. dkk (2009) ketengikan terjadi bila komponen cita-rasa dan bau yang mudah menguap terbentuk sebagai akibat kerusakan oksidatif dari minyak yang tak jenuh. Komponen-komponen ini menyebabkan bau dan cita-rasa yang tak diinginkan dalam produk minyak.
Bau minyak kelapa pada kontrol saat umur simpan 2 bulan masih memenuhi syarat SNI 3741-1995 yaitu bau normal, namun pada saat umur simpan 3 bulan sudah bau tengik sehingga tidak memenuhi syarat.

Berbeda dengan minyak kelapa yang diberi antioksidan EBT, hingga umur simpan 3 bulan bau normal sehingga memenuhi syarat SNI 3741 1995, begitu pula minyak kelapa yang diberi antioksidan BHT.

Tabel 1. Pengamatan Sifat Fisik Minyak Kelapa

\begin{tabular}{|c|c|c|c|c|c|c|}
\hline \multirow[t]{3}{*}{ Uraian } & \multicolumn{6}{|c|}{ Lama Penyimpanan } \\
\hline & \multicolumn{2}{|c|}{1 bulan } & \multicolumn{2}{|c|}{2 bulan } & \multicolumn{2}{|c|}{3 bulan } \\
\hline & Warna*) & Bau & Warna*) & Bau & Warna**) & Bau \\
\hline Kontrol & Normal & Normal & Normal & Normal & Abnormal & Tengik \\
\hline $\begin{array}{l}\text { Butylated hydroxy } \\
\text { (BHT) }\end{array}$ & & & & & & \\
\hline $100 \mathrm{~g}$ & Normal & Normal & Normal & Normal & Normal & Normal \\
\hline $150 \mathrm{~g}$ & Normal & Normal & Normal & Normal & Normal & Normal \\
\hline $200 \mathrm{~g}$ & Normal & Normal & Normal & Normal & Normal & Normal \\
\hline $\begin{array}{l}\text { Ekstrak umbi baw } \\
\text { (EBT) }\end{array}$ & & & & & & \\
\hline $100 \mathrm{~g}$ & Normal & Normal & Normal & Normal & Normal & Normal \\
\hline $150 \mathrm{~g}$ & Normal & Normal & Normal & Normal & Normal & Normal \\
\hline $200 \mathrm{~g}$ & Normal & Normal & Normal & Normal & Normal & Normal \\
\hline
\end{tabular}

Keterangan

7) Kuning muda jernin

*) Kuning kecoklatan/keruh

\section{Bilangan Peroksida}

Memperhatikan pengamatan bilangan peroksida minyak kelapa tanpa antioksidan bila dibandingan dengan pemberian antioksidan adanya kecenderungan kenaikan bilangan peroksida, sebagaimana tersaji pada Tabel 2 .

Tabel 2. Hasil Pengamatan Bilangan Peroksida dan Bilangan Asam

\begin{tabular}{|c|c|c|c|c|c|c|}
\hline \multirow[b]{3}{*}{ Uraian } & \multicolumn{6}{|c|}{ Lama Penyimpanan } \\
\hline & \multicolumn{2}{|c|}{1 bulan } & \multicolumn{2}{|c|}{2 bulan } & \multicolumn{2}{|c|}{3 bulan } \\
\hline & $\begin{array}{c}\text { Bialngan } \\
\text { Peroksida*) }\end{array}$ & $\begin{array}{l}\text { Bilanga } \\
n \\
\text { Asam*) }\end{array}$ & $\begin{array}{l}\text { Bilangan } \\
\text { Peroksida: } \\
>\end{array}$ & $\begin{array}{l}\text { Bilangan } \\
\text { Asam*) }\end{array}$ & $\begin{array}{c}\text { Bilangan } \\
\text { Peroksida*) }\end{array}$ & $\begin{array}{l}\text { Bilangan } \\
\text { Asam*) }\end{array}$ \\
\hline $\begin{array}{l}\text { Kontrol (A) } \\
\text { Butylated } \\
\text { hydroxytoluene (BHT) }\end{array}$ & 0,8985 & 1,2988 & 1,9978 & 1,3228 & 2,0706 & 1,7305 \\
\hline $100 \mathrm{mg}(\mathrm{B})$ & 0,3982 & 1,2861 & 0,4973 & 1,3079 & 1,4202 & 1,3210 \\
\hline $150 \mathrm{mg}(\mathrm{C})$ & 0,3481 & 1,2209 & 0,4471 & 1,2302 & 1,4811 & 1,3911 \\
\hline $\begin{array}{l}200 \mathrm{mg} \text { (D) } \\
\text { Ekstrak umbi bawang } \\
\text { tiwai (EBT) }\end{array}$ & 1,2469 & 1,1369 & 1,3871 & 1,1551 & 1.4921 & 1,1932 \\
\hline $100 \mathrm{mg}(\mathrm{E})$ & 0,6471 & 1,1216 & 1.0941 & 1,1551 & 1,5224 & 1,1937 \\
\hline $150 \mathrm{mg}(\mathrm{F})$ & 0,7467 & 1,1014 & 1,4919 & 1,1184 & 1,5195 & 1,1515 \\
\hline $200 \mathrm{mg}(\mathrm{G})$ & 0,7467 & 1,1014 & 1,4919 & 1,1184 & 1,5099 & 1,1216 \\
\hline
\end{tabular}

\section{Keterangan}

*) Standar Mutu Minyak Goreng SN1-3741-1995 yang bilangan peroksida dan bilangan asam adalah maks. $2 \mathrm{meg} / \mathrm{kg}$ dan maks. $0,3 \%$. 
Hal ini diduga bahwa minyak kelapa tanpa antioksidan akan mudah mengalami oksidasi, sehingga nilai bilangan peroksidanya lebih tinggi. Hal ini menunjukkan bahwa dengan adanya penambahan antioksidan ekstrak umbi bawang tiwai (EBT) mampu menekan proses terjadinya oksidasi yang terjadi di minyak kelapa, begitu pula dengan pemberian butylated hydroxytoluene (BHT).

Antioksidan menurut Riawan S (1990) merupakan zat-zat yang sangat mudah dioksidasi, karena menghalangi oksidasi zat yang bersangkutan. Antioksidan yang biasa dipakai adalah hidroquinon.

Menurut Winarno

menyatakan kerusakan minyak yang utama adalah timbulnya bau dan rasa tengik yaitu proses ketengikan, dimulai dengan pembentukan radikal-radikal bebas yang disebabkan oleh faktorfaktor yang dapat mempercepat reaksi seperti cahaya dan panas. Rekasi oksidasi ini dapat juga berlangsung bila terjadi kontak antara sejumlah oksigen dengan minyak. Terjadinya rekasi oksidasi ini akan mengakibatkan bau tengik pada minyak.

Selanjutnya dikatakan proses ketengikan sangat dipengaruhi oleh adanya prooksidan dan antioksidan akan menghambatnya. Penyimpanan minyak yang baik adalah dalam tempat tertutup yang gelap dan dingin.

Diperjelas Gaman dan Sherrington (1994) bahwa oksidasi terjadi hasil reaksi antara trigliserida tidak jenuh dan oksigen dari udara. Molekul oksigen bergabung pada ikatan ganda molekul trigliserida dan dapat terbentuk berbagai senyawa yang menimbulkan rasa tengik yang tidak sedap. Reksi ini dipercepat oleh panas, cahaya dan logam-logam dalam konsentrasi amat kecil, khususnya logam tembaga.

Menurut Winarno (1997) bahwa adanya antioksidan dalam minyak akan mengurangi kecepatan proses oksidasi. Antioksidan sintetis yang biasa digunakan antara lain butylated hydroxytoluene (BHT), butylated hydroxyanisole (BHA), propylgallate (PG) dan Nordihidroguairetic acid (NDGA). Antioksidan sintetik yang banyak digunakan sekarang adalah senyawa-senyawa fenol yang bersifat racun. Sedangkan antioksidan alami biasanya yang digunakan untuk antioksidan adalah Tokoferol, Karotenoid, Asam askorbat dan senyawa fenolik.

\section{Bilangan Asam}

Bilangan asam menunjukkan banyaknya asam lemak bebas dalam minyak dan dinyatakan dengan $\mathrm{mg}$ basa per 1 gram minyak.

Bila memperhatikan bilangan asam pada kontrol minyak kelapa tanpa pemberian antioksidan terlihat adanya kecendrungan naik, hal ini menunjukkan banyaknya asam lemak bebas yang terbentuk, sehinga bilangan asam cenderung naik.

Berbeda dengan bilangan asam pada minyak kelapa yang diberi antioksidan EBT dan BHT, hal ini menunjukkan bahwa antioksidan EBT mampu menekan proses kenaikan asam lemak bebas pada minyak kelapa, begitu pula minyak kelapa yang diberi antioksidan BHT.

Adanya kecenderungan naiknya bilangan asam yang ada dalam minyak hal ini akibat terjadi reaksi hidrolisis pada minyak terutama pada saat pengolahan.

Menurut Winarno menyatakan dengan adanya air, lemak dapat terhidrolisis menjadi gliserol dan asam lemak. Reaksi ini dipercepat oleh basa, asam dan enzim-enzim. Hidrolisis sangat mudah terjadi dalam lemak dengan asam lemak rendah (lebih kecil dari $\mathrm{C}_{14}$ ) seperti minyak kelapa.

Hal yang sama dikemukakan oleh Buckle, dkk (2009) pada proses 
hidrolisa minyak akan menghasilkan asam-asam lemak bebas yang dapat mempengaruhi cita rasa dan bau dari pada bahan. Hidrolisa dapat disebabkan oleh adanya air dalam minyak atau karena kegiatan enzim.

Ditambahkan oleh ketaren $S$ (1986) Reaksi hidrolisa akan mengakibatkan ketengikan hidrolisa yang menghasilkan flavor dan bau tengik pada minyak, minyak akan diubah menjadi asam-asam lemak bebas dan gliserol. Asam lemak bebas (bilangan asam) berdasarkan SNI-3741$1995 \max 0,3 \%$.

\section{KESIMPULAN DAN SARAN}

Dari hasil penelitian dapat disimpulkan bahwa ekstrak umbi bawang tiwai (EBT) dengan konsentrasi 100 - $200 \quad \mathrm{mg} / \mathrm{kg}$ mampu mempertahankan umur simpan minyak kelapa hingga 3 bulan.

\section{DAFTAR PUSTAKA}

Andarwulan, N., H. Wijaya, dan D.T. Cahyono. 1996. Aktivitas Antioksidan dari Daun Sirih (Piper betieL), Jurnal Teknologi dan Industri Pangan, Volume VII, Nomor 1. Fakultas Teknologi Pertanian, IPB. Bogor.

Badan Standardisasi Nasional 1995. SNI 3741-1995. Standar Mutu Minyak Goreng. Badan Standardisasi Nasional. Jakarta.

Buckle A.K., Edwards A.R., Fleet H.G. dan Wotton M. 2009. Ilmu Pangan, Penerjemah Purnomo $\mathrm{H}$ dan Adiono. Universitas Indonesia. Jakarta.
Gaman P.M dan Sherrington K.B. 1994. IImu Pangan, Pengantar IImu Pangan, Nutrisi dan Mikrobiologi. Terjemahan Gardjito M, Naruki S, Murdiati A dan Sardjono. Gadjah Mada University Press. Yogyakarta.

Kateran S.N. 1986. Pengantar Teknologi Minyak dan Lemak Pangan. Universitas Indonesia. Jakarta.

Riawan S. 1990. Kimia Organik. Binarupa Aksara. Jakarta.

Saputra H.S. 2010. Aktivitas Antioksidan Ekstrak Umbi Bawang Tiwai (Eleutherine americana Merr). Jurnal Riset Teknologi Industri Volume 4 Nomor 1 Bulan Juni 2010. Balai Riset dan Standardisasi Industri. Samarinda.

Suroto HS., dan Sampepana E. 2007. Analisa Kandungan Kimia Dan Pemanfaatan Bawang Tiwai (Eleutherine americana Merr) Untuk Bahan Baku Industri. Jurnal Riset Teknologi Industri. Balai Riset dan Standardisasi Industri Volume 1 Nomor 1 Bulan Juni Tahun 2007. Samarinda.

Suroto HS. 2007. Analisa Bioktif Dan Pemanfaatan Bawang Tiwai (Eleutherine americana Merr) Untuk Bahan Tambahan Pangan. Jurnal Riset Teknologi Industri Volume 1 Nomor 2 Bulan Desember 2007. Balai Riset dan Standardisasi Industri. Samarinda.

Winarno F.G. 1997. Kimia Pangan dan Gizi. PT. Gramedia Pustaka Utama Jakarta. 